\title{
THE CATEGORY OF THE NATION STATE IN THE LIGHT OF REQUIREMENTS REGARDING CONTEMPORARY PROCESSES OF SHAPING PUBLIC POLICIES
}

\begin{abstract}
During the 2019 campaign to the European Parliament, it was often argued that the situation in which EU institutions can make decisions that de facto legally affect public authorities of a given state in shaping policies on its territory violates this state's sovereignty. Another argument was that such a situation would seriously limit the possibility of satisfying the needs of citizens of the state in question. The above logic assumes that maintaining the principles of the nation state with regard to a state's political system would guarantee the citizens greater control over public decisions and ensure that their needs are met. This type of argumentation has been present for a long time in the discourse on Poland's membership in the European Union.

The objective of the presented research is to elucidate what exactly it would mean for an average citizen (considering their potential influence on shaping public policies) to introduce a political system based on the so often evoked category of the nation state in its original, literal sense. To meet the above objective, the text presents the original meaning of the category of the nation state and its constituent parts, followed by an analysis whether and possibly why
\end{abstract}


the understanding of these elements has evolved. Finally, the entire cognitive process leads to a firm conclusion that a return to political relations based on the classical approach to the category of the nation state would lead to contemporarily unacceptable effects on the position of individuals in democratic political systems. This also means that the categories of the nation state and sovereignty can evolve and a discussion on the changing scope of their meaning is fully acceptable.

\section{Key words}

nation state, governance, sovereignty

\section{Research aim and methodology}

What inspired the analysis presented in this paper was the wide-ranging discussion that continued in Poland and in some way in the whole of Europe during the election campaign to the European Parliament (EP). According to the trend which has been observed for years, campaigns to the EP are to a great extent treated as a kind of plebiscite regarding a state's policy and an assessment of local political forces. Thus only few issues raised in the campaign concerned the matters of the European Union's (EU) competence, particularly the Parliament. If any aspects related to the EU were referred to, they very often revolved around the membership in the EU and were characterized by a high level of generality rather than by focusing on any specific, detailed issues (such as an assessment of the work of a given member of the European Parliament (MEP) in their working committees or of competence of a given candidate to perform the MEP function). With a view to the above, often raised was the issue of EU institutions with specific authority to shape public policies which are then binding for Poland as a member state and hence result in undermining the essence of the nation state as a legal-political construct ${ }^{1}$. Therefore it was not a rare argument that it is a violation of a state's sovereignty when EU institutions can take decisions de facto binding for the public authorities of a given state when it comes to shaping policies on its territory. Another argument was that such a situation

1 The discussion also concerned the question whether EU institutions are expanding this scope and whether it is in line with what the Member States would agree on when signing EU treaties (founding, accession and reforming ones). These issues are part of a long-time political debate in Poland about the sovereignty of the Member States and the models of their functioning in the EU. 
would seriously limit the possibility of satisfying the needs of Polish citizens (see e.g. the websites: PCh.pl Polonia Christiana, 2019; Radio Maryja, 2016; Prawo i Sprawiedliwość, 2019; on the first decade of Poland's membership in the EU and the attitudes towards Poland's position, see Master, 2014, pp. 57-65, 71-73). Thus such a point of view assumes that maintaining the principles of the nation state would guarantee the citizens greater control over public decisions and ensure that their needs are met.

Paradoxically, the author's interest in this place has not been raised so much by the question whether EU membership violates state sovereignty as this issue has been repeatedly discussed and subjected to analyses in legal contexts and political science ${ }^{2}$. In light of popularity of the aforementioned kind of arguments and its constant presence in public debate, the author asked the following question: considering the potential impact of an average citizen (voter) on shaping public policies (or their position in the authority-society relationship in the process of making public decisions), what exactly would it mean for the said citizen to maintain the so often connoted primary, essential meaning of the category of the nation state, or - in the language of the methodology of the conducted research - the scope of the abovementioned category?

A research goal so defined simultaneously imposes the scope of the chosen research field. Its time is framed by the period from the emergence of the analyzed category to the present day. The substantive scope will include defining the category of the nation state or its essential components. An equally important aspect will be the necessity to determine whether the scope of meaning of individual components has undergone modifications, and if so, for what reasons. In terms of its subject, the analysis will focus on the citizen and the category of the sovereign in the nation state as well as on the citizen's needs and the ways they can be satisfied through shaping public policies. Hence to answer the main research question, it is necessary to address certain specific issues: first and foremost, when the concept of the nation state was formulated and what it means precisely; what its components are and how they should be understood; additionally, which requirements were met by the occurring changes in the scope of meaning of individual components defining the nation state. It is also necessary to present the entities in the political system entitled to shape public policies in the nation state as well as to demonstrate what maintaining the original meaning of the category would mean for its citizens.

2 The issue will be referred to further in this analysis. 
In order to make the cognitive process as reliable as possible, the author starts his work with formulating a hypothesis (in line with the spirit of the cited concepts) that maintaining the requirements set for the basic meaning of the category of the nation state would result in far greater opportunities to satisfy the needs of citizens of such a state. Hence the author initially assumes that with regard to the functioning of political systems and to decision-making processes, using the category of the nation state (and sovereignty) in its basic meaning is more beneficial for an average citizen.

The research problem formulated here will be approached mainly through content analysis. Also, when defining individual research categories, it will be particularly useful to apply the method of critical discourse analysis. Another method - process tracing - will be adopted during the stage of identifying and attempting to explain causal relations falling within the scope of the research field. The choice and application of the above methods allow them to interpenetrate and complement each other.

\section{Inclusion of the category of the nation state in the analysis of public policy-shaping processes}

The concept of the nation state still remains the starting point (or the basis) determining the position of a state and the decision-making model in relations of the authorities with the subjects as well as with other entities in the international arena (mainly other states). This concept was introduced at the turn of the $17^{\text {th }}$ century in Europe ${ }^{3}$. Since then, through imperialism and colonization, it has become global.

The beginnings of the idea to build such a political system should be traced back to the moment when absolutist regimes were being shaped in Europe. Merging or absorbing smaller political structures by stronger ones also resulted in the strengthening of a clearly defined center that could shape collective human behavior by making decisions and enforcing them. Political power understood in this way (for more on the issue of defining power, see Bankowicz, 2006, pp. 25-27) was held by individual monarchs. On the one hand, they were no longer dependent on church authorities, but on the other - they were anointed

${ }^{3}$ It is often believed that nation states became a universal political and social form of organization after the Treaty of Westphalia of 1648 , and reached its peak between the $17^{\text {th }}$ and mid- $20^{\text {th }}$ century. 
to perform their role by God's mandate, which gave them extensive legitimation and great independence in making final decisions. The rulers were sovereigns in their states, and states' structures were to serve the implementations of the rulers' decisions and the satisfaction of their needs ${ }^{4}$. Thus it is no surprise that one of the basic features of an absolutist state was the fact that it was to be a political structure, put in motion by energy and controlled by information flowing from one center established to coordinate multiple tasks (Poggi, 1978, p. 98). With such approach, a state (and de facto its authorities) could not only claim for itself absolute power within its borders but all states could also claim independence from each other. By rejecting the supremacy of popes and emperors at the end of the Middle Ages, monarchs ensured independence of their lands from other countries. Besides making their own laws - in compliance with the etymological meaning of the word autonomos - the states ensured also that regulations of other entities had no effect on them. (Morris, 2004, p. 198). Thus in Westphalian sense, the main task of all international relations was to maintain balance between sovereign actors in the international arena (Zielonka, 2007, p. 123). This led to perceiving a state as a political unit in which the authority was to be wielded by a clearly defined power center - a monarch who exercised his power over subjects in a given territory. It should not be surprising, however, that within these concepts a nation - understood as an ethnic community (Canovan, 2006 , p. 353) - was only an object of governance, and not its subject.

Thus formulated concept of the nation state consists of a narrow center of power capable of making unaided decisions, independent of broad groups of internal entities; a center of power with superior authority over its territory, whose competence cannot be challenged by any external entities; and also a nation, understood in its ethnical sense.

The aforementioned situation also had certain results in the perception of security as it was possible to clearly separate its internal and external aspects. The external aspect of security was identified with the ability to counteract threats posed by other state actors. Usually, those were military threats which involved interference in the functioning of institutions as well as in the norms established by sovereign bodies of state authority. In turn, internal security was limited to activities conducted in a given country by its relevant institutions and services (appointed to fulfil these tasks). The sources of threats to internal security were endogenous, while the spreading of crime was limited by strictly controlled state

4 The essence of this view has remained to this day; however, what has fundamentally changed is the concept of the sovereign itself. 
borders and by tight regulations on crossing them and on the entry and stay of foreigners on the territory of a given state (Gruszczak, 2011, p. 138).

\section{Who rules here, or the evolution of domestic authority-society relationship since the formulation of the concept of the nation state}

It should be admitted that outlining the concept of the nation state in the above way, i.e. traditional/original approach, clearly limited the participation of other entities in the process of framing public policies, leaving it in the hands of the internal center of power. Importantly, however, this limitation concerned external as well as internal factors that remained outside this very center.

However, this concept soon became a subject of criticism and voices rose demanding its modification. Contrary to the currently most often discussed aspects of this construction, i.e. references to the form of external relations, in the first place it concerned relations within a state as a political organization. At that time, the rejection of papal authority gave rise to fully separate secular state authority. Simultaneously, a state expanded its areas of interest and increased the number of legal regulations. Thus the demand for strong and efficient administration grew as well, which inevitably required the participation of an increasing number of citizens. Due to the specificity of the new tasks, this administration had to build relations with society not only by using coercion but also through appreciating the contribution of individual citizens, e.g. in the developing industry. This led to stronger emphasis on the importance of individual entities for the functioning of a state and also made it necessary to determine how far the interference of a sovereign and their administration could go, and where the impassable limit of the private sphere of each citizen was. Another important factor was the development of science and art, which began to increasingly emphasize the subjectivity of individual people and the importance of satisfying needs of individual citizens ${ }^{5}$.

All this rapidly changed the view on legitimacy of the authorities and on the role which a citizen had to fulfil. There appeared concepts suggesting a clear departure from the original perception of the position and role of a sovereign.

${ }^{5}$ Already at that time there existed concepts which differed in terms of exercising political power. Following the ideas born in ancient Greece (mainly Athens) and Rome, such thinkers as Marsilius of Padua and later Machiavelli clearly adhered to republican models of governance. The core of their assumption was the exercise of power by society. 
Although the first steps, made by i.e. Hobbes, seemed hardly revolutionary, the increasing scope of sovereign's interests and the resulting public decisions of their administration forced a clear indication of where the private sphere of citizens was located and where public authorities could not have authority (see Hobbes, 1651/2009). At that point the views of Locke and then Montesquieu were already clearly outlined. Drawing upon the autonomous perception of a citizen, they strongly demanded explicit recognition of a certain sphere independent of the interference of the authority - the private sphere encompassing family life, property right and trade. With regard to the public sphere, they claimed that since power comes from the people, the authorities were only to execute it. This concept was developed particularly by Montesquieu, who envisioned a state in which delimitation of power branches is an imperative. A nation would exercise its right to enact the law through its representatives. As a consequence, another branch was necessary to implement this law, i.e. the executive, which could be in the hands of a monarch and all administrative institutions (see Monteskiusz, 1748/2003; Locke, 1689/1992). The ideas of Jean-Jacques Rousseau, who represented clearly republican views, were also important for the development of the concept of power in states. Although his concept, based on the assumption that only decisions adopted each time by the general public can be considered valid (see Rousseau, 1762/1948), was not precisely reflected in political reality, it did play an indisputable role in shaping the concept that a nation, not a ruler, is the sovereign.

What makes those ideas all the more significant is the fact that they became the signposts for the political changes in Europe in the 18th century ${ }^{6}$. The emergence of the United States, followed by the French Revolution, which emphasized the sovereignty of the nation, the subjectivity of citizens, respect for their rights and their ability to control the authorities, embodied liberal models of representative democracy. Thus the paradigm of the sovereign entity in a state changed completely. It was therefore a fundamental departure from the original understanding of the category of the nation state in terms of the relationship between the ruling and the ruled. The sovereign state was still an entity subject

6 Systematically supplemented and clarified over time by the works of James Madison, Jeremy Bentham and James Mill, who postulated the nowadays obvious mechanisms of citizens' control over those who rule them, such as regular elections, competition between candidates for representative bodies, secrecy of voting (see Madison, Hamilton, Jay, 2001, pp. 193-195, 273-275, Bentham, 1843, pp. 96-98, 106-110, O’Rourke, 2001, pp. 76-84, 94-100). 
to the decisions made by the sovereign; however, it was the nation, not a single ruler, that was the sovereign and the nation's needs were to be satisfied in the first place.

However, still the discussions continued as to who should make decisions about public policy and in what way it was to be done. Implementation of the republican decision-making mechanism seemed impossible as the states were already too well developed territorially and had too big population to guarantee each of their citizens the opportunity to physically participate in making decisions. Moreover, with the increase in the number of tasks falling to states as well as in the dynamics of relations within political systems and in the scope of public policies, it was necessary to make faster decisions. This resulted in the need to specialize as it was impossible for everyone to have adequate knowledge to properly solve a specific problem. Hence, a logical solution was to exercise the nation's power (the right to take binding decisions) through its representatives. The nation became the one who bestowed legitimacy on entities designated to make decisions. What became a crucial issue was the process of fair elections, which would give a real chance to assess and change the authorities (on the importance of elections as an essential element of the model of modern democracies see e.g. Dahl, 1989, pp. 221, 233; Held, 2010, pp. 121-123). Obviously, the role of the ruler, or at that time already more broadly - the government apparatus, also had to change and became the tool for realizing the will of the nation - the sovereign.

However, this fundamental systemic change could not mean the end of modifications. What cannot be forgotten when analyzing the perception of entities authorized to make public decisions and the extent of the impact of the state apparatus is the fact that the development of civilization and the increase in private ownership, entrepreneurship and trade exchange within the free market, which had been observed over the centuries, resulted in the arduously developed limitation of the state's interference (i.e. limiting its plenipotentiary power) in these spheres of life of non-public entities (Held, 2010, pp. 100-101). It was becoming clear that since the citizen is not any property belonging to the king, but is part of the collective sovereign, the scope of powers given to the state apparatus would depend on the citizen. This meant that certain aspects of life could be regulated by citizens according to their individual discretion, and state structures not only could not intervene in them if there was no critical need to do so (e.g. disaster, war), but also they should protect their integrity through public decisions. Additionally, or perhaps above all, although for that time revolutionary views on the category of national sovereignty and power were coming from the nation, the authors of liberal concepts promoted the increased 
autonomy of citizens but excluded from this category a significant number of people, such as women, slaves and often poor citizens (e.g. Bentham, 1843, pp. 108-109; for more on this topic see Held, 2010, pp. 121-123). Hence, next decades were characterized by the pursuit of new groups and environments, so far disenfranchised, to participate in those activities. It is only since that time that certain organized structures started to flourish, achieving increasing successes. Those organizations included e.g. women's emancipation movement and groups opposing women's segregation. Their activities did not end until the second half of the 20th century and resulted in the granting of electoral rights to these social groups and in the extension of basic political rights to all citizens (see Lisowska, 2009, pp. 24-46; U.S. Department of the Interior, 2009, pp. 3-118).

However, achieving this stage did not close the discussion on the models of political systems related to the state's internal relation between the ruling and the ruled. One of the next important steps in the development of civilization in the $20^{\text {th }}$ century was the gradual inclusion of social and economic rights into the canon of civil rights. Except that, the discussion focused on the extent, apart from the electoral act itself, where the participation of non-public entities in the decision-making process was required. Here, the crisis of the late 1960s and early 1970s was an unquestionable shock to the understanding of political order in democratic countries. The justification for that state of affairs was sought in various sources, while two approaches entered the mainstream. On the one hand, the reason for it was seen in the excessive state interference and the excessive submission to new demands held within welfare state; on the other hand - in the detachment of the ruling sphere from the real problems of citizens and thus the loss of legitimacy to make public decisions. As a consequence, there were basically two different proposals to change the situation, or rather two trends towards its improvement.

Proponents of the first trend, i.e. the neoliberal approach, supported the idea of limiting state interference in intra-market relations and leaving to its mechanisms the distribution of goods and resources. This attitude was expressed by, for example, Robert Nozick (see Williams, 2006, pp. 490-495). On the other hand, there were opposing ideas saying about an increase in direct social participation in current public decisions. Such proposals included i.a. an increase in participatory democracy at the lowest levels of the functioning - brought forward by e.g. Carole Pateman (see Pateman, 19707) - and the later concepts of deliberative

7 The author agrees with John Stuart Mill and states that education and involvement at local level may increase the general level of participation (Pateman, 1970, p. 33). 
democracy, which implied that it was necessary for a society to discuss, explain and make decisions after due consideration in all public matters. The most radical supporters of that trend were i.e. Iris Marion Young and John Dryzek, who treated their concept as a new model of democracy in general (Dryzek, 2009, pp. 1385-1387; Young, 2002, pp. 21-23). However, with regard to the neoliberal trend and the above views, which called for an increase in public participation in shaping public policies, certain reservation could be expressed ${ }^{89}$. Both trends proposed too radical solutions to be fully implemented.

Importantly, considering participation at the level of local authorities, she points to workplaces as the main centres where individuals could and should acquire appropriate customs as she maintains that in many aspects workplaces are a system similar to the political system of managing public policies. Thus the more people participate at this level, the more they learn about this issue and increase their willingness to participate at different levels (Pateman, 1970, pp. 42-43, 66, 72, 105)

${ }^{8}$ With regard to neoliberal approach, it is difficult not to point out that sometimes the very structure of market and social stratification was the reason for conflicts and social unrest, making it as a consequence difficult to operate a private business. It must not be forgotten that there have been threats that the market of a given country may not be able to overcome without help from the authorities, such as e.g. increased threat of unfair competition from subjects with global reach, or the malpractices of certain states using markets to pursue their policies. Also, or perhaps above all, with the development of free market so advanced, it was difficult to negate ideas opposite to neoliberalism that private business entrepreneurs have an immense influence on public policy matters such as employment, social issues, development of innovations or even education (understood as gaining qualifications). This in turn enforced a change in perception of the private sphere and the idea of the lack of connection between the public life and the business sphere. Unsurprisingly, in some cases public authorities also wanted to interfere in these spheres of activity.

${ }^{9}$ Considering Pateman's views, it is difficult not to notice that she omitted may spheres or domains where participation of non-public subjects could be seen as desirable and where participation-related competences and habits could be acquired equally well. Practical difficulties could be noticed either only at the local level (particularly regarding workplaces) as in the case of the new left, or in any kind of political decisions as in the case of deliberative democracy. A conscious, involved citizen who deliberates at any time, particularly when the situation concerns them, is a construct that hardly can be considered undesirable. However, in a general social approach this should be treated as a sort of a theoretical model, unattainable in everyday conditions of contemporary expanded systems of Western civilization. It is difficult to imagine a society so educated that each of its representatives was conscious of what is necessary and competent enough to participate every time when a public decision is in the making (e.g. regarding taxes, public investments or modern technologies). There is no space here at all for non-public 
This does not mean, however, that the very assessment of the situation made by the representatives of both views - the assessment which constituted the basis for their ideas -was not correct and that the fundamental problem was wrongly identified. On the contrary, both trends presented a similar diagnosis, i.e. the loss of credibility by the ruling elite and the lack of public trust in their decisions. Hence, the election itself, although was to remain a condition for a democratic state, could not alone meet the growing social demands. It will be therefore right to assume that for political systems of Western democracies the aim of the search over the past decades has been (and still is) to create such a model for managing the process of framing public policy that would ensure social acceptance of the authorities as well as the citizens' trust. This would also result from an even clearer assumption that the number of tasks currently facing public authorities, their multi-faceted nature, comprehensiveness and interdisciplinary much too far exceeded the capabilities of one entity to have all the required knowledge and skills (Kooiman, 2000, p. 142). It is also noticeable that the method in which decisions are made only by the authorities (even with support from experts) and without the broadly understood society has one more disadvantage. Sometimes the problems are so complex that it is difficult to decide what would be optimal for a given community. In such situations there is a possibility for interested parties to have their say (Wojciuk, 2012, pp. 6-7). The desired model for managing the process of framing public policy would be at the same time a system for effectively satisfying social needs, which would not interfere beyond their acceptable measures in the private sphere, i.e. flexible enough to facilitate selection of such tasks and methods of their implementation that would closely reflect social requirements (Kułak-Krzysiak, 2014, p. 61).

In this perspective, subsequent proposals were made to reform the model of managing public decision-making, which were also to change the position of non-public entities in these relations (see Goodin et al., 2006). What may seem a relatively apt answer to such challenges is the contemporary concept of public governance, which is yet another, after new public management (NMP), proposal of performing public administration ${ }^{10}$. Naturally, this concept has its

subjects, uninterested in participation in the process of public decision-making (see Frieske \& Pawlowska, 2011, p. 78; Fung, 2006, p. 670).

${ }^{10}$ New public management referred to the organization and management theory and attempted to transfer to public administration the principles and institutions characteristic for business (corporation) management). The flagship of this conception was considering a person/ citizen/resident of a given territory as a consumer/client of public administration, while the administration was seen as a provider of public services/ 
variations; however, to show its essence, it is necessary to indicate certain common elements. First of all, what is meant here is the support of the theory of networks, which as a form of governance are based on making the possibility of achieving assumed goals dependent on the simultaneous interaction of many entities, or even on the interdependence between various organizational units. Therefore, the decision-making process of the public structure is about including non-public actors. Network structure is understood as an organization in which coordination is replaced by hierarchy through horizontal relations, and the assets are located in a way that the producer of the finished whole is the network and not any of the individual partners (Małecka-Łyszczek, 2014, p. 47). In the case of governance, this interaction can occur both between various levels, i.e. vertically, and between many areas, i.e. horizontally (Heritier \& Lehmkuhl, 2008, p. 1). Thus one of the most striking aspects of this approach to management is that it redefines the position of society from being the object of governance, which is a burden on the rulers, to the position of a potential resource (a certain political force), which must be activated in the process of good (i.e. effective, efficient and democratic) public management (Sørensen \& Triantafillou, 2009, p. 1).

The above means that public entities agree to share their powers to make arbitrary political decisions in a certain way as it is to be done by non-hierarchical control measures. Therefore, it is a voluntary and mutual solution of common problems of the state, the market and the sphere of non-public entities of a nonprofit nature, in transparent conditions that can be subject to verification before institutions of representative democracy (Gualini, 2005, p. 298; see also Zybała, 2013, pp. 10, 12). This means that the new public governance model may be a compromise between the requirements of modern governance and neoliberal views of the functioning of the market as - despite the fact that according to this theory, public authorities can decide about market functioning - they are not to do it arbitrarily and entrepreneurs have the full right to speak and influence decisions made in these matters. On the other hand, this does not automatically imply an obligation to participate, as predicted by theories of deliberative democracy. The decision on possible participation in these processes belongs to non-public entities, and so there is room for their various doubts and hesitation. Therefore they can decide on their own whether they wish to take part in the process of creating public policies in order to meet their individual needs. However, what is important, when they do, they take on part of the responsibility

intangible services of social importance, while public services were contracted according to free-market rules (Niżnik-Dobosz, 2014, p. 43). 
for the effects (Chambers \& Kopstein, 2006, p. 375). It can thus be said that this model is based on cooperation between the parties interested, not coercion or any imperative decision-making, and the new public governance is not (at the same time) a model intended to displace liberal representative democracy, which still remains the basic model of relations between citizens and the authority. It is only a variant of it, a specific qualified type which also assumes direct participation of non-public entities in shaping public policies, i.e. participatory democracy (Gualini, 2005, p. 298; Kaźmierczak, 2011, p. 92; Niżnik-Dobosz, 2014, pp. 26-27).

\section{Evolution of other elements of the nation-state category}

What also changed with the progress of civilization were factors influencing another element necessary for the existence of the political construct of the nation state, i.e. independence of decisions from external factors (Zielonka, 2007 , p. 123). From the start, this situation raised specific questions related to the dynamics of the processes occurring in the sphere of international relations already at the very beginnings of the conception of the nation state. The late $19^{\text {th }}$ and the $20^{\text {th }}$ century in particular brought an inundation of factors that ultimately forced fundamental modifications of opinions on full independence of individual nation states within their borders.

Both world wars certainly demonstrated emphatically and very painfully that no state is able to dominate other actors on international relations, nor can any state feel fully safe on its own. When the development of military technologies of mass destruction and their effects was added to this equation, the status of a state untouched by the outcome of possible future military conflicts became questionable. Furthermore, from the mid- $20^{\text {th }} \mathrm{c}$. entirely new threats have been gaining strength, such as internationalization of criminal groups and intensification of terrorism. Their growth significantly contributed to blurring of the boundary between internal and external aspect of national security as well as of the previously clear delimitation of exo- and endogenous threats (Gruszczak, 2011, p. 138). Today nobody wonders at the situation when an organized criminal group active in the territory of a specific state consists mostly of people who are not its citizens. Contemporary reality includes also situations when terrorist groups recruit or plan attacks electronically and can be carried out successfully outside the borders of a target country. The current situation is the outcome of the changed character of the threats and from the fact that the state institutions 
which regulate behaviors in spheres governed by public policies (including sanctions and punishments for behaviors and acts that violate such regulations) have increasingly limited possibilities of enforcing these regulations through the state administrative apparatus (see Bigo, 2000; Gruszczak, 2011, pp. 137-139). As a result of these developments, internal security (against traditional conceptions of this sphere of a state's activity) has crossed the territorial boundaries of nation states. It even led to the creation of international political networks including institutions and organs responsible for activities on the international arena that initiate transnational processes (Bigo, 2000, p. 184). Thus the evolution of threats and the necessity to combat them led to the states opening to exchange of sensitive data: as they needed access to personal, process and operational data possessed by other states in order to combat potential contemporary threats, the states themselves agreed to giving other actors of international relations access to such content and to transferring such information. Moreover, this twoway opening also involves increasingly frequent actual cooperation of public forces (e.g. the police) of different states or simplified procedures of transferring persons across state borders (e.g. with the European Arrest Warrant (EAW)).

Further factors appeared in particular after World War II; they not only concerned security issues but also majorly influenced the present shape of national security. The currently emerging forms of managing international markets and other economic processes involve national governments; however, the role of the latter has been somewhat redefined. Globalization techniques, growth of international markets and internationalization of corporation structures put pressure on the nation states to focus more on competitiveness and standards of effectiveness. In response, state policy-makers follow the signals from the international system that suggest applying solutions used in market economy to political problems and opening to free market competition (Bulmer, 2007, pp. 4-5).

The significance of a variety of international organizations is growing as well. States function increasingly as components of international "political society", where their role is legitimization and ensuring responsibility of supranational and subnational governance mechanisms (Hirst \& Thompson, 1996, p. 171).

The particular case of the EU represents a very advanced integration process which has led to the formation of a unique system of division and management of competence groups in public policy-making.

On the one hand, this means the vertical division of competences along the EU-member states axis. As a result of the process of integration, the EU by now has acquired a volume of exclusive competences where states cannot make independent decisions. On principle, this includes matters related to the tariff 
union, establishing the competition rules necessary for the functioning of the internal market, common trade policy as well as monetary policy with regard to the states using the euro as the currency (TFEU, art. 3, section 1). It should be noted, that to a great extent this refers to the matters which are fundamental for each stage of integration which apparently cannot be implemented without the supremacy of supranational authorities over national ones, which can justify the situation. However, the main range of matters where the EU may act are the so-called shared competences, where the activity of both the EU and member states is acceptable. This involves such spheres as internal market, economic, social and territorial coherence, transport, and consumer protection (TFEU, art. 4 section 2). These competences are exercised according to the principle of subsidiarity. Where it applies, the EU acts only when, and only to an extent in which specific objectives cannot be achieved satisfactorily by member states at central, regional or local level - and only if due to the scale or effects of the proposed action those objectives can be better achieved at the EU level (TEU, art. 5, section 3$)^{11}$.

On the other hand, we deal here with a very particular system of the EU institutions and horizontal division of competences between these institutions. Part of the EU institutions have intergovernmental character (the European Council and the Council of the European Union). They comprise mostly the representatives of the executive of the member states, and a large number of decisions are made by majority vote, not unanimously, which also diverges from the principles of the classical model of international state cooperation (Rada Unii Europejskiej, 2018; Witkowska-Chrzczonowicz, 2014). In turn, some institutions with very extensive competences and a significant role in decision making process have supranational character. Their members are not answerable to the governments of the member states they come form, those members represent either the interests of the EU as an organization (primarily the European Commission and the Court of Justice of the EU) (Nugent \& Rhinard, 2015; Witkowska-Chrzczonowicz, 2008; see also Stone Sweet, 2010), or directly the interests of the citizens who elect their representatives (the European Parliament) (Węc, 2015). A particular feature of the EU's system here is that the basic method of adopting legal acts is the so-called "ordinary legislative procedure", each time involving intergovernmental as well as supranational institutions (see Bazylińska-Nagler, 2015;

11 At present, every project of an EU legal act which is to go through further steps of the law-making process must contain a justification, including a confirmation that the described conditions have occurred. 
Węc, 2015, pp. 15-27). Another important element of public policy-making in the EU is the competence of the Court of Justice of the EU to make binding interpretation of EU regulations, which actually influences the ultimate shape of the regulations in force in the EU (Szachoń, 2010, p. 167). According to literature on the EU's law, this competence enables the Court to pass rulings with causative power close to that of precedents ${ }^{12}$.

A search for the reasons of changes made to decision-making processes of the EU system leads to a conclusion that with the years that passed since the integration process began, as the benefits of mutual opening to economic cooperation became increasingly noticeable and the economic needs of the member states' citizens were better and better satisfied, the competences of the Communities with regard to building the common market were gradually expanded, which resulted also in the expansion of the scope of the elements included in integration processes (see Ginsberg, 2007, pp. 230-235). The initially adopted formula turned out to be poorly adjusted to new conditions and challenges the Communities faced with regard to public policy-making. Thus it became necessary to facilitate decision-making processes i.e. to speed it up and avoid the risk of decision paralysis, which was becoming increasingly likely with the growing number of member states and policies included in the integration process. Hence subsequent treaties abandoned procedures requiring unanimity in intergovernmental institutions (see Rada Unii Europejskiej, 2016, pp. 25-37). On the other hand, the success of the integration process, from which a growing number of citizens and private enterprises began to draw benefits, depended on effective introduction of uniform rules of the EU system for all members (such as the rule of fair competition in the common market and free movement of persons, goods etc.) and combating protectionist practices. This situation in practice led to systematic increase of participation and importance of supranational institutions. A crucial example here can be the growing significance of the Court of Justice and its rulings (see Czapliński et al, 2001, pp. 24-25, 373-413; Jaremba, 2014, pp. 45-112; Stone Sweet, 2010). The increased importance of supranational institutions can be also partially ascribed to the intention to separate at least to some extent the decision making processes from the game of states' political interests and to protect against the risk that decision-making processes will be dominated by the strongest states. As more and more everyday matters were regulated within the $\mathrm{EU}$ decision-making processes, an important factor was

12 This situation is currently accepted by e.g. Polish decision-making bodies. See Haczkowska \& Jabłoński, 2015, p. 150; cf. Baran, 2014, pp. 367-398, 420-434. 
also the willingness to increase the possibility of influencing decisions made in such a way (and of legitimizing them) by the citizens of the member states - hence the European Parliament's competences and role in decision making process has been increasing with every system reform (see Słok-Wódkowska, 2015, pp. 66-68; Szczerski \& Telejko, 2015).

Considering the evolution of political systems from the perspective of the state, it can be stated that by joining the process of European integration, those states agreed - in the form of (foundation, accession or later reform) treaties to share certain duties that in the past were the sole competences of individual nations. Thus by sharing packets of their competences the European countries accepted limitations of the formerly indivisible feature of sovereignty in exchange for benefits from the possibilities offered by actions of joint authorities and achieving common goals (Schmidt, 2006, pp. 10-11). By being EU members, the states agree to functioning within the accepted scheme of division of competences, institutional system and decision-making procedures (more on the complexities of shaping public policies in the EU, see Ruszkowski, 2013).

Returning to the level of general deliberations as to the category of the nation state, it is difficult not to note the influence of new technologies, the internet in particular, on free movement of e.g. information between - or even despite physical boundaries between states. The same technologies that contributed to spreading the conceptions of civil rights and educating the society have become also a platform for making business, finance management and entertainment - and, as mentioned earlier, a place for committing forbidden acts or a tool in the hands of crime or terrorist groups, enabling them to reach beyond the physical borders of individual states.

Consequently, it should be admitted that Manuel Castellas was right when he stated that, due to the abovementioned circumstances of civilization progress, over the past decades nation states transformed from independent subjects to strategic actors, promoting their interests in the global system of interactions in the conditions of systematically shared sovereignty. They gain significant influence, but exercise their power in a network of mutual relations with supranational macropowers and subnational micro-processes (Castells, 2008, pp. 330-331).

The political perturbation of the last century, development of globalization and international trade led to increased movement of factors of production. All this clearly left its mark on another pillar of the traditionally understood nation state, i.e. ethnically understood conception of a nation. The category of territorially defined nation state was used as a mental shortcut to ensure spatial coherence between a specific legal system (representing that state or issued 
by it) and the subjects subordinate to it (understood in turn as a society based on ethnicity). Today such an understanding of nation is becoming problematic as the societies of many states are becoming multicultural. Individual persons who feel connection with their current state and identify with it politically and culturally can point to their ethnic origins, which in no small amount of cases can be traced even to another continent. Social denationalization is thus notice$a_{b l e}{ }^{13}$. These processes have advanced so far that there is a number of voices saying - as e.g. Sylvia Walby (2003) - that it is necessary to rethink the conception of a "society", which is so often put on a par with the "nation state". Walby states (and it is difficult to ignore her arguments) that there are four significant reasons why identifying society with the nation state is difficult today. Firstly, there are more nations than states ${ }^{14}$. Secondly, in their heyday, many of the oft-quoted examples, assumed to be nation states, were de facto empires ${ }^{15}$. Besides, we deal now with overlapping of political systems, not adhering to the popular myth of sovereignty of a nation state over the territory it owns. It means that economic, political and cultural spheres of connections do not overlap too precisely with separate political organisms (nation states) ${ }^{16}$. And finally, apart from states there exist various significant political organizations - including the European Union - and some organized religions as well as emerging multilateral and global forms of governance (or rather of making international political decisions) (Walby, 2003, pp. 530-539; see also Saward, 2006, pp. 400-419).

${ }^{13}$ Michael Zürn uses the term "denationalization", which he perceives as weakening of the connection between territorial states and nation societies; this connection is a necessary condition for a national constellation (or a political construction) to exist. Therefore denationalization can be defined as expansion of social spheres, which are created by numerous transactions occurring over state borders (though not necessarily on a global scale). Yet although the reach of most of these relations is not global, they still pose a problem for state governments for the simple reason that the mentioned social sphere is no longer strictly national (Zürn, 2000, p. 188).

${ }^{14}$ A territory inhabited by a single nation, within one state organism is a very rare occurrence. There are also nations without their own state.

15 The most evident examples include France and Great Britain, which actually were once, as mentioned, most popular examples of empires, not nation states.

${ }^{16}$ The spheres of influence of various political organizations intersect, without saturating a specific territory in political sense. Different types of political system subjects may govern different spheres of social life. For example, the church and the state can divide between them institutions over which they claim jurisdiction. Sometimes the subjects (of a political system) agree to division of jurisdiction, either openly or by acceptance of the status quo; in other cases such situation can be questioned, with full consequences. 
In consequence, it is difficult to deny that in many states enjoying the effects of the civilizational progress the understanding of the category of "nation" is expanding as it also includes a multi-cultural civil society, inhabiting a specific territory, united by values that can be implemented and protected (which includes ensuring security) only within a state structure. In this meaning, nation is a civil form of society - not necessarily ethnically homogenous, but unified around similarly understood goals (Heywood, 2010, pp. 136-138). These issues are clearly distinguished in German, where the notion of das Kulturvolk signifies an ethnic community, and das Staatsvolk - a society unified by shared living or public interest. On the grounds of politics, it is even more evident in the American system. In the US, to be a citizen automatically means to be a member of the nation (thus the famous "We the People" reference to nation in the constitution, which can be read as identifying a nation based on civic society with the state) (Canovan, 2006, pp. 353-355). According to such definition of a nation, persons without multigenerational traditions and relationship with a given territory are considered a valuable addition to their society as long as they have similar values, actually believe that a given state should exist and develop, and are ready to consciously become its part and work for its benefit. Thus from this perspective, a state is understood as a large (also territorially), formalized social organization equipped with a government apparatus. It comprises the entire population of a given territory, subjected to norms and rules that constitute its internal order and define all rights and obligations.

\section{Conclusions}

The above analysis allows drawing conclusions regarding the research problem. First, it was possible to determine that the category of the nation state that emerged in the $17^{\text {th }} \mathrm{c}$. has certain fundamental constituents: it requires determining the sovereign within the state, the internal relations between the rulers and the ruled, the relations with other international subjects, and the understanding of the category of the nation. The analysis also produced a precise definition of each of the above concepts according to the approach initially used. However, it soon became evident that each of these elements evolved in some way due to civilization-building processes - social, economic and technological as well as those related to the issues of security and combating threats. Consequently, the conception of the nation state has evolved over centuries. What changed was the attitude to non-intervention of external factors into internal making of 
social policies. In this area, states as well as international organisations (whose role here seems to grow) will be considered as a sort of nodes in a more extensive network of power (Castells, 2008, p. 324). The perception of nation has also changed towards civic approach; yet the most significant transformation was the concept of the sovereign itself as well as perception of the role of citizens in decision-making processes. In this sphere, the contemporary Western states follow the liberal-democratic model; furthermore, in the last decades we also witnessed a discussion on how to efficiently and effectively approach shaping public policies in democratic states. A solution that is emerging is a model unqualifyingly founded on free elections allowing alternation in power, and simultaneously - broad-scope acceptance of other forms of public participation. It is thus a model of action that on the one hand allows public entities to have increased information scope and means at their disposal, and on the other hand it can increase legitimacy of adopted solutions, and spread responsibility among all participants of such an emerging network (Fung, 2006, pp. 681-683; see also Tusalem, 2007, pp. 378-380).

Therefore, considering the question what it would mean for an average citizen to maintain the oft-evoked, basic meaning of the nation state in the aspect of its potential influence on shaping public policies, it should be categorically stated that the resulting position of individuals in democratic political systems would be unacceptable today. This fact seems to be overlooked when references are made to the necessity of applying in international relations the nation-state category and so emphasized classical approach to sovereignty. If in turn an assumption is made that any references to the categories of sovereignty and the nation state should be limited to only some of their elements, with the exclusion of the internal relation between the rulers and the ruled, several other essential aspects must be first discussed here as well.

It is difficult to overlook the fact that the above analysis demonstrates clearly that the contemporary development of civilization led to the point when effective satisfaction of the citizens' needs far exceeds the possibilities of that state's central power, both in the internal and external aspect of the state. This can be seen e.g. in the necessity to make public decisions that match the demands of local communities and receive the broadest possible support from the citizens, as well as in measures counteracting security threats when the dichotomy between internal and external aspect is blurring, or in participation in globalized trade and in the possible flow of the factors of production. This situation forces state authorities to participate in a variety of formats of public decision-making, often unknown and untried. Therefore if a sine qua non condition of realization of 
the abovementioned assumptions is altered perception of each constituent of the nation-state category, abandoning such formula of understanding any of them would lead to diminished possibilities of even partial participation in shaping relevant public policies as well as meeting the citizen's needs in a developed Western state operating in a globalized world.

Furthermore, considering the matter from purely axiological point of view, if the very definition of the nation state - where the cornerstone is the sovereignruler and their independence - could be so drastically altered in the discussed aspect, why not modify its other aspects as well? All the more as each case of altering the understanding of individual constituents is caused by the discussed civilizational transformations and attempts to satisfy new social needs. It can be thus stated that the actual debate on the category of the nation state and its sovereignty does not concern upholding the definition or changing it, but actually focuses on the scope of acceptable modification as all participants in such debates accept a degree of modification from the beginning.

\section{REFERENCES}

Bankowicz, M. (2006). Demokracja. Zasady, procedury, instytucje. Kraków: Wydawnictwo Uniwersytetu Jagiellońskiego.

Baran, M. (2014). Stosowanie z urzędu prawa Unii Europejskiej przez sądy krajowe. Warszawa: Wolters Kluwer Polska.

Bazylińska-Nagler, J. (2015). Procedury legislacyjne - podstawowy tryb decyzyjny UE. In J. Galster, \& A. Szczerba-Zawada (eds.), Procedury decyzyjne Unii Europejskiej (pp. 41-63). Warszawa: Instytut Wydawniczy EuroPrawo.

Bentham, J. (1843), Vol IX: Constitutional Code. In J. Bowring (ed.), The works of Jeremy Bentham. Edinburgh: William Tait. Retrieved from https://oll.libertyfund.org/ titles/bentham-works-of-jeremy-bentham-11-vols

Bigo, D. (2000). When two become one. Internal and external securitisations in Europe. In M. Kelstrup, \& M. C. Williams (eds.), International Relations Theory and the Politics of European Integration. Power, Security and Community (pp. 171-204). London-New York: Routledge.

Bulmer, S., Dolowitz, D., Humphreys, P., \& Padgett S., (2007). Policy Transfer in European Union Governance: Regulating the Utilities. London-New York: Routledge.

Canovan, M. (2006). The people. In J. S. Dryzek, B. Hong, \& A. Phillips (eds.), The Oxford Handbook of Political Theory (pp. 349-362). New York: Oxford University Press. DOI: 10.1093/oxfordhb/9780199548439.001.0001

Castells, M. (2008). Siła tożsamości. Warszawa: Wydawnictwo Naukowe PWN. 
Chambers, S., \& Kopstein, J. (2006). Civil society and the state. In J. S. Dryzek, B. Hong, \& A. Phillips (eds.), The Oxford Handbook of Political Theory (pp. 363-381). New York: Oxford University Press. DOI: 10.1093/oxfordhb/9780199548439.001.0001

Czapliński, W., Ostrihansky, R., Saganek, P., \& Wyrozumska, A. (2001). Prawo Wspólnot Europejskich. Orzecznictwo. Warszawa: Wydawnictwo Naukowe Scholar.

Dahl, R. A. (1989). Democracy and Its Critics. New Haven: Yale University Press.

Dryzek, J. (2009). Democratization as Deliberative Capacity Building. Comparative Political Studies, 11(42), 1379-1402.

Frieske, K. W., \& Pawłowska, K. (2011). Obywatelska partycypacja: migotanie idei. In A. Olech (ed.), Partycypacja publiczna. O uczestnictwie obywateli $w$ życiu wspólnoty lokalnej (pp. 61-79). Warszawa: Instytut Spraw Publicznych.

Fung, A. (2006). Democratizing the policy process. In M. Moran, M. Rein, \& R. E. Goodin (eds.), The Oxford Handbook of Public Policy (pp. 669-685). New York: Oxford University Press. DOI: 10.1093/oxfordhb/9780199548453.001.0001

Ginsberg, R. H. (2007). Demystifying the European union: the enduring logic of regional integration. Plymouth: Rowman and Littlefield Publishers.

Goodin, R. E., Rein, M., \& Moran, M. (2006). The Public and its Policies. In M. Moran, M. Rein, \& R. E. Goodin (eds.), The Oxford Handbook of Public Policy (pp. 3-34). New York: Oxford University Press. DOI: 10.1093/oxfordhb/9780199548453.001.0001

Gruszczak, A. (2011). Strategiczne aspekty walki z terroryzmem w Unii Europejskiej. In R. Potorski (ed.), Wspólpraca policyjna i sądowa w sprawach karnych w Unii Europejskiej. Geneza, struktury, działania (pp. 135-157). Toruń: Wydawnictwo Adam Marszałek.

Gualini, E. (2005). Reconnecting Space, Place, and Institutions: Inquiring into 'Local' Governance Capacity in Urban and Regional Research. In L. Albrechts, \& S. J. Mandelbaum (eds.), The Network Society. A New Context for Planning? (pp. 272-307). London: Routledge.

Haczkowska, M., \& Jabłoński, M. (2015). Proceduralno-prawne aspekty stanowienia ustaw przez polskiego prawodawcę w świetle zasady pierwszeństwa prawa unijnego. In M. Jabłoński, \& S. Jarosz-Żukowska (eds.), Zasada pierwszeństwa prawa Unii Europejskiej w praktyce działania organów władzy publicznej RP (pp. 149-170). Wrocław: Uniwersytet Wrocławski.

Held, D. (2010). Modele demokracji. Kraków: Wydawnictwo Uniwersytetu Jagiellońskiego.

Heritier, A., \& Lehmkuhl, D. (2008). Introduction. The Shadow of Hierarchy and New Modes of Governance. In Journal of Public Policy, 1(28), 1-17.

Heywood, A. (2010). Politologia. Warszawa: Wydawnictwo Naukowe PWN.

Hirst, P., \& Thompson, G. (1996). Globalization in Question: the International Economy and the Possibilities of Governance. Cambridge: Polity Press.

Hobbes, T. (2009). Lewiatan czyli materia, forma i władza państwa kościelnego i świeckiego (C. Znamierowski, trans.). Warszawa: Fundacja Aletheia. (Original work published 1651) 
Jaremba, U. (2014). National Judges As EU Law Judges: The Polish Civil Law System. Leiden-Boston: Martinus Nijhoff Publishers.

Kaźmierczak, T. (2011). Partycypacja publiczna: pojęcie, ramy teoretyczne. In A. Olech (ed.), Partycypacja publiczna. O uczestnictwie obywateli w życiu wspólnoty lokalnej (pp. 83-99). Warszawa: Instytut Spraw Publicznych.

Kooiman, J. (2000). Societal governance: Level, Models and Orders of Social-Political Interaction. In J. Pierre (ed.), Debating Governance, Authority, Steering and Democracy (pp. 138-164). New York: Oxford University Press.

Kułak-Krzysiak, K. (2014). Partycypacja czy efektywność? Dylematy skutecznego osiągania celów w administracji publicznej. In B. Dolnicki (ed.), Partycypacja społeczna w samorzadzie terytorialnym (pp. 58-66). Warszawa: Wolters Kluwer Polska.

Lisowska, E. (2009). Równouprawnienie kobiet i mężczyzn w społeczeństwie. Warszawa: Oficyna Wydawnicza SGH.

Locke, J. (1992). Dwa traktaty o rządzie (Z. Rau, trans.). Warszawa: PWN. (Original work published 1689)

Madison, J., Hamilton, A., \& Jay, J. (2001). The federalist. Indianapolis: Liberty Fund. Accessible online http://files.libertyfund.org/files/788/0084_LFeBk.pdf

Małecka-Łyszczek, M. (2014). Partycypacja w ramach public governance. In B. Dolnicki (ed.), Partycypacja społeczna $w$ samorzadzie terytorialnym (pp. 44-57). Warszawa: Wolters Kluwer Polska.

Master, B. (2014). Unia Europejska w programach głównych polskich ugrupowań politycznych po 2004 roku. Studia Politicae Universitatis Silesiensis, (12), 42-77.

Monteskiusz (Montesquieu). (2003). O duchu praw (T. Boy-Żeleński, trans.), Kraków: Wydawnictwo Znak. (Original work published 1748)

Morris, C. W. (2004). Modern State. In G. F. Gaus, \& C. Kukathas (eds.), Handbook of Political Theory (pp. 195-209). London-Thousand Oaks, CA-New Delhi: Sage Publications.

Niżnik-Dobosz, I. (2014). Partycypacja jako pojęcie i instytucja demokratycznego państwa prawnego i prawa administracyjnego. In B. Dolnicki (ed.), Partycypacja społeczna w samorzadzie terytorialnym (pp. 21-43). Warszawa: Wolters Kluwer Polska.

Nugent, N., \& Rhinard, M. (eds.). (2015). The European Commission ( $2^{\text {nd }}$ ed.). LondonNew York: Palgrave.

O'Rourke, K. C. (2001). John Stuart Mill and Freedom of Expression: The Genesis of a Theory. London: Routledge.

Pateman, C. (1970). Participation and Democratic Theory. Cambridge: Cambridge University Press. Retrieved from http://ebooks.cambridge.org/ebook.jsf?bid=CBO9780511720444 Poggi, G. (1978). The Development of the Modern State. Stanford: Stanford University Press. PCh.pl Polonia Christiana [website]. (2019, May 1). Marsz Suwerenności przeszedł przez Warszawę. Antifa próbowała zablokować manifestację. Retrieved from https://www. pch24.pl/marsz-suwerennosci-przeszedl-przez-warszawe--antifa-probowala-zablok owac-manifestacje,67926,i.html 
Radio Maryja [website]. (2019, Jun 27). J. Kaczyński: Państwa narodowe powinny mieć więcej suwerenności. Retrieved from https://www.radiomaryja.pl/informacje/jkaczynski-panstwa-narodowe-powinny-miec-wiecej-suwerennosci/

Rada Unii Europejskiej. (2016). Historia Rady Europejskiej i Rady UE. Integracja europejska - podejmowanie decyzji i tworzenie prawa. Luksemburg: Urząd Publikacji Unii Europejskiej. Retrieved from https://www.consilium.europa.eu/media/29965/ qc0415219pln.pdf

Rada Unii Europejskiej. (2018). Rada Europejska i Rada UE. Dom Europa, Luksemburg: Urząd Publikacji Unii Europejskiej.

Rhodes, R. A. W. (1996), The New Governance: Governing without Government. Political Studies, 4(44), 652-667.

Rhodes, R. A. W. (2008). Understanding Governance: Policy Networks, Governance, Reflexivity and Accountability. Maidenhead: Open University Press.

Rousseau, J. J. (1948). Umowa Społeczna (A. Peretiatkowicz, trans.). Łódź: Marian Ginter Księgarnia Wydawnictw Prawniczych i Naukowych. (Original work published 1762)

Ruszkowski, J. (2013). Struktura wielopoziomowego zarządzania w Unii Europejskiej. In J. Ruszkowski, \& L. Wojnicz (eds.), Multi-level Governance w Unii Europejskiej (pp. 19-60). Szczecin-Warszawa: Instytut Politologii i Europeistyki Uniwersytetu Szczecińskiego, Instytut Europeistyki Uniwersytetu Warszawskiego.

Saward, M. (2006). Democracy and citizenship: expanding domains. In J. S. Dryzek, B. Hong, \& A. Phillips (eds.), The Oxford Handbook of Political Theory (pp. 400-419). New York: Oxford University Press. DOI: 10.1093/oxfordhb/9780199548439.001.0001 Schmidt, V. A. (2006), Democracy in Europe: the EU and National Polities. New York: Oxford University Press.

Słok-Wódkowska, M. (2015). Decydowanie publiczne w Parlamencie Europejskim. Remedium na tzw. deficyt demokracji? In J. Galster, \& A. Szczerba-Zawada (eds.), Procedury decyzyjne Unii Europejskiej (pp. 65-90). Warszawa: Instytut Wydawniczy EuroPrawo.

Sørensen, E., \& Triantafillou, P. (2009). The Politics of Self-Governance: An Introduction. In E. Sørensen, \& P. Triantafillou, The Politics of Self-Governance (pp. 1-22). Farnham-Burlington: Ashgate.

Stone Sweet, A. (2010). The European Court of Justice and the judicialization of EU governance. Living Reviews in European Governance, 2(5), 1-50.

Szachoń, A. (2010). Źródła prawa Unii Europejskiej. In A. Kuś (ed.), Prawo Unii Europejskiej $z$ uwzględnieniem Traktatu $z$ Lizbony (pp. 165-234). Lublin: Wydawnictwo KUL.

Szczerski, K., \& Telejko, B. (2015). Ewolucja roli Parlamentu Europejskiego w systemie politycznym UE. In A. Kirpsza, P. Musiałek, \& D. Stolnicki (eds.), Podsumowanie siódmej kadencji Parlamentu europejskiego (pp. 39-51). Kraków: AT Wydawnictwo. Treaty on European Union (TEU), 7 Feb 1992, Official Journal of the European Communities 29.07.1992, C 191, 1-112. 
Treaty on the Functioning of the European Union (TFEU, consolidated version), 13 Dec 2007, Official Journal of the European Union, 26.10.2012, C 326, 47-201.

Tusalem, R. F. (2007). A Boon or a Bane? The Role of Civil Society in Third- and FourthWave Democracies. International Political Science Review, 3(28), pp. 361-386.

U.S. Department of the Interior. (2007, revised 2009). Civil Rights in America: Racial Voting Rights. Retrieved from https://www.nps.gov/subjects/tellingallamericansstories/upload/CivilRights_VotingRights.pdf

Walby, S. (2003). The Myth of the Nation-State: Theorizing Society and Polities in a Global Era. Sociology, 3(37), 529-546.

Węc, J. J. (2015). Pozycja parlamentu Europejskiego w reżimie traktatu lizbońskiego. In A. Kirpsza, P. Musiałek, \& D. Stolnicki (eds.), Podsumowanie siódmej kadencji Parlamentu europejskiego (pp. 13-35). Kraków: AT Wydawnictwo.

Williams, A. (2006). Liberty, equality and property. In J. S. Dryzek, B. Hong, \& A. Phillips (eds.), The Oxford Handbook of Political Theory (pp. 488-506). New York: Oxford University Press. DOI: 10.1093/oxfordhb/9780199548439.001.0001

Witkowska-Chrzczonowicz, K. (2008). Pozycja prawna Komisji Europejskiej w systemie instytucjonalnym Wspólnot Europejskich. Toruń: TNOiK.

Witkowska-Chrzczonowicz, K. (2014). Dynamika rozwoju Rady Europejskiej w systemie instytucjonalnym Unii Europejskiej. Studium prawno-ustrojowe. Toruń: TNOiK.

Wojciuk, A. (2012). Wstęp. In A. Wojciuk, Analiza pracy administracji na wybranym problemem polityki publicznej z punktu widzenia jakości konsultacji społecznych (pp. 5-9). Warszawa: Krajowa Szkoła Administracji Publicznej.

Young, I. M. (2002). Inclusion and Democracy. New York: Oxford University Press.

Zielonka, J. (2007). Europa jako imperium. Nowe spojrzenie na Unię Europejska, Warszawa: Polski Instytut Spraw Międzynarodowych.

Zürn, M. (2000). Democratic Governance Beyond the Nation-State: The EU and Other International Institutions. European Journal of International Relations 6, 183-221. Zybała, A. (2013). Wyzwania w sektorze publicznym. Animacja Życia Publicznego Zeszyty Centrum Badań Społeczności i Polityk Lokalnych, 1(8), 9-12. 